\title{
Effect of Chemicals on Growth, Yield and Quality of Elephant Foot Yam [Amorphophallus paeoniifolius (Dennst.) Nicolson]
}

\author{
Samatha Punna ${ }^{1 *}$, K.D. Desai ${ }^{1}$, B.M. Tandel ${ }^{2}$ and Harish Suthar ${ }^{3}$ \\ ${ }^{1}$ Department of Vegetable Science, ${ }^{2}$ Department of Fruit Science, ${ }^{3}$ Department of Post- \\ Harvest Technology, ASPEE College of Horticulture and Forestry, Navsari Agricultural \\ University, Navsari, Gujarat, India \\ *Corresponding author
}

\section{A B S T R A C T}

The present investigation entitled "Effect of chemicals on growth, yield and quality of elephant foot yam" was carried out at AICRP on Tuber Crops, Regional Horticultural Research Station, Navsari Agricultural University, Navsari (Gujarat) during the year 201718. The experiment was conducted in Randomized Block Design (RBD) with three

\section{Keywords}

Plant growth regulators, Chemicals, Soaking treatment, Elephant foot yam

Article Info

Accepted: 08 July 2018 Available Online: 10 August 2018 replications and eleven treatments consisting of different chemicals (Thiourea: 200 and 300 ppm; $\mathrm{KNO}_{3}$ : 500 and 750 ppm; $\mathrm{GA}_{3}$ : 100 and 200 ppm; CCC: 50 and 75 ppm; MH: 250 and $500 \mathrm{ppm}$ and water soaked i.e. control) with different concentrations. The setts of $250 \mathrm{~g}( \pm 50 \mathrm{~g})$ were soaked in the solution for one hour as per the treatments. Among all soaking treatments, Thiourea $200 \mathrm{ppm}$ was found most effective in days required for first emergence (20.00 days), plant height at 120 and 150 DAP $(63.73 \mathrm{~cm}$ and $63.29 \mathrm{~cm}$, respectively), culm girth at 120 and 150 DAP $(15.57 \mathrm{~cm}$ and $16.29 \mathrm{~cm}$, respectively), petiole length at 120 and 150 DAP $(52.80 \mathrm{~cm}$ and $53.67 \mathrm{~cm}$, respectively), number of leaflets per plant at 90 and 150 DAP (297.53 and 311.93, respectively). Yield attributes viz., corm diameter $(14.82 \mathrm{~cm})$, corm yield per plant $(1.315 \mathrm{~kg})$, yield per net plot $(17.367$ $\mathrm{kg}$ ) and yield per hectare $(30.15 \mathrm{t})$ were also recorded highest in $\mathrm{T}_{1}$ treatment whereas, maximum number of cormels (3.13) per corm were found in $\mathrm{T}_{3}\left(\mathrm{KNO}_{3} 500 \mathrm{ppm}\right)$ treatment. Quality attributes viz., dry matter content $(32.60 \%)$ and beta-carotene (VitaminA) content $(147.13 \mathrm{IU})$ were found maximum in $\mathrm{T}_{2}$ treatment whereas, the highest starch content $(17.80 \%)$ was found in $\mathrm{T}_{1}$ treatment. Lowest amount of calcium oxalate content $(0.0200 \%)$ was found in $\mathrm{T}_{10}(\mathrm{MH}-500 \mathrm{ppm})$ treatment.

\section{Introduction}

Elephant foot yam (Amorphophallus paeoniifolius Dennst. Nicolson) is a tropical tuber crop belonging to family Araceae. It is considered as a famine food in the pacific Islands. It is gaining popularity as a cash crop among the farming community of our country due to its high production potential, higher biological efficiency, acceptable culinary 
properties, medicinal utility and therapeutic values. It is commercially cultivated as annual, generally bearing one to few broad highly dissected leaf with long petiole and rhizomatous stem called corm (Nicolson, 1987). The corms are rich in starch and are used as staple food. The corm is consumed as a vegetable after boiling, baking and frying (Nedunchezhiyan et al., 2002). In northern and eastern states, wild and local cultivars are generally grown for making pickles. It has high dry matter production capacity per unit area than most of the other vegetables.

The most popular variety for commercial cultivation in our country is "Gajendra", which is a local selection from Kovvur, West Godavari district of Andhra Pradesh. It has high yielding potential with vigorous growing habit. The corms are smooth, hemispherical and depressed in the centre, 20-25 cm diameter and usually dull-yellowish brown colour at harvest. The corms are also free from acridity, produce less or no cormels and have better quality of flesh.

Plant growth regulators and some of the chemicals are synthetic organic compounds other than nutrients which modify or regulate or inhibit or promote, plant physiological processes in an appreciable measure when used in small concentrations. They are readily absorbed and these chemicals move rapidly through the tissues when applied to different plant parts. Many of these chemical compounds have been manufactured and tested and it is seen that the behaviour and response of each crop is highly variable according to the composition and concentration of the compounds. In other words, these compounds are specific in their action. These synthetic PGRs are put into several uses in horticulture, one of them is to increase crop yield and improve quality. The growth behaviour of many plants could be modified or controlled by applying small amount of plant growth regulators, either by seed soaking, root dipping, spraying or drenching.

Commercially available plant growth regulators (PGRs) and plant growth enhancers (PGEs) are relatively recent agricultural advances. These products have the promise to increase crop production, fertilizer and water use efficiency and the profitability of agricultural production. They may play an ever increasing role in food and fibre production.

\section{Materials and Methods}

The present experiment was carried out at AICRP on Tuber Crops, Regional Horticultural Research Station, Navsari Agricultural University, Navsari (Gujarat) during the year 2017-18. The experiment was conducted in Randomized Block Design (RBD) with three replications. The setts of $250 \mathrm{~g}( \pm 50 \mathrm{~g})$ were soaked for one hour in different solutions as per treatments viz., Thiourea $200 \mathrm{ppm}\left(\mathrm{T}_{1}\right)$, Thiourea $300 \mathrm{ppm}$ $\left(\mathrm{T}_{2}\right), \mathrm{KNO}_{3} 500 \mathrm{ppm}\left(\mathrm{T}_{3}\right), \mathrm{KNO}_{3} 750 \mathrm{ppm}$ $\left(\mathrm{T}_{4}\right), \mathrm{GA}_{3} 100 \mathrm{ppm}\left(\mathrm{T}_{5}\right), \mathrm{GA}_{3} 200 \mathrm{ppm}\left(\mathrm{T}_{6}\right)$, CCC 50 ppm $\left(\mathrm{T}_{7}\right)$, CCC $75 \mathrm{ppm}\left(\mathrm{T}_{8}\right), \mathrm{MH} 250$ ppm $\left(\mathrm{T}_{9}\right), \mathrm{MH} 500 \mathrm{ppm}\left(\mathrm{T}_{10}\right)$ and Water soaked i.e. control $\left(\mathrm{T}_{11}\right)$. The treated setts were shade dried for 3 days and planted at $60 \mathrm{~cm} \mathrm{x}$ $60 \mathrm{~cm}$ distance on $22^{\text {nd }}$ March, 2017. FYM (25 t/ha) was incorporated at the time of soil preparation. Recommended dose of 100: 50: $150 \mathrm{NPK} \mathrm{kg} / \mathrm{ha}$ was applied out of which 50 $\% \mathrm{~N}, 50 \% \mathrm{~K}_{2} \mathrm{O}$ with $100 \% \mathrm{P}_{2} \mathrm{O}_{5}$ was applied at the time of planting. At 30 DAP, $25 \% \mathrm{~N}$ and $\mathrm{K}_{2} \mathrm{O}$ was applied immediately after first intercultural operation. Similarly, remaining $25 \%$ of $\mathrm{N}$ and $\mathrm{K}_{2} \mathrm{O}$ were applied immediately after second intercultural operation at 60 DAP.

The bio-chemical analysis was done immediately after harvesting the corms. The starch and calcium oxalate content was 
analyzed with the procedure given by Padmaja et al., (2005) while dry matter content and $\beta$ carotene content was analyzed with respect to the procedure of (A.O.A.C., 1960).

\section{Results and Discussion}

Growth parameters like days required for first and $50 \%$ emergence, plant height, culm girth, petiole length, number of leaflets per plant and days required for senescence were influenced by soaking of setts in different chemicals. Among different chemical treatments, thiourea treated corm setts produced better effect on emergence. The minimum number of days to first emergence (20.00 days) was recorded under $\mathrm{T}_{1}$ (Thiourea - $200 \mathrm{ppm}$ ) treatment which was statistically remained at par with almost all the treatments in inducing early emergence except $T_{8}, T_{10}$ and $T_{11}$ treatments. The minimum number of days (31.33 days) to 50 per cent emergence was recorded under $T_{2}$ (Thiourea - $300 \mathrm{ppm}$ ) treatment which was statistically remained at par with $\mathrm{T}_{1}$ and $\mathrm{T}_{3}$ (Thiourea - $200 \mathrm{ppm}$ and $\mathrm{KNO}_{3}-500 \mathrm{ppm}$, respectively) treatments which required 32.00 and 37.00 days, respectively for $50 \%$ emergence. These results are in conformity with the findings of Nedunchezhiyan et al., (2011) who reported that thiourea was most effective in inducing earliness in first sprouting. Naveen et al., (2011) reported that reduction in the number of days for sprouting and sprouting percentage due to thiourea can be attributed to two reasons. The first being their effect in reducing the ABA levels, the prime factor imposing dormancy in corms and cormels and there by changing the endogenous hormonal balance in favour of promoters. Secondly, increase in quantum of alternate respiration due to these treatments. ABA is considered to be a principal endogenous regulator of dormancy in corms. The occurrence of alternate respiration mediated by alternate oxidase (AOX) and its positive correlation during seed germination has been reported in crops like chickpea (Burguillo and Gregorio, 1997).

It is evident from table 1 that plant height, culm girth, petiole length showed nonsignificant difference at 90 DAP. Statistical analysis of the data revealed that at 120 and 150 DAP maximum plant height $(63.73 \mathrm{~cm}$ and $63.29 \mathrm{~cm}$, respectively) was recorded in treatment $T_{1}$ which was statistically remained at par with $\mathrm{T}_{2}, \mathrm{~T}_{3}, \mathrm{~T}_{5}, \mathrm{~T}_{4}$ and $\mathrm{T}_{6}$ treatments. The maximum petiole length $(52.80 \mathrm{~cm}$ at 120 DAP and $53.67 \mathrm{~cm}$ at 150 DAP) was also measured in same $T_{1}$ treatment which was remained at par with $T_{2}, T_{3}, T_{5}$ and $T_{4}$ treatments at both growth stages (Table 1). Significant effect on culm girth was observed at both group stages. Maximum culm girth $(15.57 \mathrm{~cm}$ at 120 DAP and $16.30 \mathrm{~cm}$ at 150 DAP) was recorded in $T_{1}$ treatment which was statistically remained at par with $\mathrm{T}_{2}, \mathrm{~T}_{3}, \mathrm{~T}_{5}$ and $\mathrm{T}_{6}$ treatments (Table 1). Similar results were reported by Ravi et al., (2009) and Das et al., (1995) in elephant foot yam. The taller plants under these treatments might be due to early sprouting observed under the present study. The grand growth period involving high physiological activity synchronized with maximum nutrient uptake may have aided to increase plant height and thereafter at 150 DAP marginal increase in plant height may be attributed to the rapid increase in corm growth and also because of diversion of more photosynthates from source (leaves) to sink (corm) which is most common phenomenon in almost all root and tuber crops Ravi et al., (2009).

The effect of different treatments on canopy spread of elephant foot yam in both directions was measured and found that among all three growth stages i.e. 90, 120 and 150 DAP the significant result was obtained only at 120 DAP in E-W direction (Table 1) where maximum spread $(72.13 \mathrm{~cm})$ was recorded in $\mathrm{T}_{2}$ (Thiourea $300 \mathrm{ppm}$ ) treatment. 
Table.1 Effect of soaking treatments on growth parameters of elephant foot yam cv. Gajendra

\begin{tabular}{|c|c|c|c|c|c|c|c|c|c|c|c|c|c|c|}
\hline \multirow[t]{3}{*}{ Treatments } & \multicolumn{14}{|c|}{ Growth parameters } \\
\hline & \multicolumn{2}{|c|}{$\begin{array}{l}\text { Days required } \\
\text { for emergence }\end{array}$} & \multicolumn{3}{|c|}{ Plant height } & \multicolumn{3}{|c|}{ Petiole length } & \multicolumn{3}{|c|}{ Culm girth } & \multicolumn{3}{|c|}{ Canopy spread E-W } \\
\hline & $\begin{array}{c}\text { First } \\
\text { emerg. }\end{array}$ & $\begin{array}{c}50 \% \\
\text { emerg. }\end{array}$ & $\begin{array}{c}90 \\
\text { DAP }\end{array}$ & $\begin{array}{c}120 \\
\text { DAP }\end{array}$ & $\begin{array}{c}150 \\
\text { DAP }\end{array}$ & $\begin{array}{c}90 \\
\text { DAP }\end{array}$ & $\begin{array}{c}120 \\
\text { DAP }\end{array}$ & $\begin{array}{c}150 \\
\text { DAP }\end{array}$ & $\begin{array}{c}90 \\
\text { DAP }\end{array}$ & $\begin{array}{c}120 \\
\text { DAP }\end{array}$ & $\begin{array}{c}150 \\
\text { DAP }\end{array}$ & $\begin{array}{c}90 \\
\text { DAP }\end{array}$ & $\begin{array}{c}120 \\
\text { DAP }\end{array}$ & $\begin{array}{c}150 \\
\text { DAP }\end{array}$ \\
\hline $\mathbf{T}_{1}$ & 20.00 & 32.00 & 51.00 & 63.73 & 63.29 & 36.20 & 52.80 & 53.67 & 13.23 & 15.57 & 16.30 & 69.73 & 70.00 & 70.60 \\
\hline $\mathbf{T}_{2}$ & 20.33 & 31.33 & 49.07 & 63.17 & 62.53 & 35.06 & 51.87 & 52.73 & 12.23 & 14.67 & 15.50 & 65.00 & 72.13 & 69.33 \\
\hline $\mathbf{T}_{3}$ & 20.67 & 37.00 & 49.00 & 60.67 & 62.03 & 34.60 & 49.13 & 52.67 & 12.37 & 14.43 & 15.30 & 64.33 & 69.27 & 66.67 \\
\hline $\mathbf{T}_{4}$ & 21.67 & 39.33 & 46.27 & 59.00 & 59.67 & 32.20 & 48.73 & 49.93 & 12.10 & 14.20 & 14.90 & 60.93 & 67.00 & 64.33 \\
\hline $\mathbf{T}_{5}$ & 20.67 & 38.00 & 47.33 & 59.80 & 60.23 & 32.06 & 48.80 & 50.60 & 12.23 & 14.40 & 15.07 & 62.80 & 68.13 & 65.33 \\
\hline $\mathbf{T}_{6}$ & 21.67 & 40.67 & 45.27 & 58.07 & 57.80 & 30.30 & 47.73 & 48.27 & 11.87 & 13.70 & 14.40 & 60.40 & 67.00 & 64.00 \\
\hline $\mathbf{T}_{7}$ & 22.67 & 42.33 & 41.67 & 52.07 & 52.83 & 28.03 & 41.47 & 43.53 & 11.17 & 12.33 & 13.10 & 55.33 & 63.27 & 63.33 \\
\hline $\mathbf{T}_{8}$ & 32.67 & 47.33 & 38.80 & 49.80 & 50.13 & 25.80 & 37.73 & 39.73 & 10.63 & 11.97 & 12.77 & 54.13 & 59.20 & 61.13 \\
\hline $\mathbf{T}_{9}$ & 22.33 & 40.67 & 40.93 & 53.47 & 53.67 & 30.60 & 42.90 & 44.80 & 11.40 & 12.53 & 13.43 & 57.00 & 63.47 & 63.67 \\
\hline $\mathbf{T}_{10}$ & 24.67 & 46.00 & 38.93 & 51.87 & 52.60 & 28.00 & 39.00 & 43.33 & 10.77 & 12.03 & 12.80 & 55.20 & 59.47 & 61.67 \\
\hline$T_{11}$ & 32.67 & 49.33 & 43.27 & 54.27 & 54.47 & 26.00 & 43.77 & 44.80 & 10.60 & 13.20 & 14.00 & 54.06 & 64.40 & 63.67 \\
\hline $\mathrm{SEm} \pm$ & 1.23 & 2.12 & 2.83 & 2.86 & 2.82 & 2.38 & 2.82 & 2.59 & 0.66 & 0.73 & 0.73 & 4.30 & 2.73 & 2.72 \\
\hline C. D. $(5 \%)$ & 3.62 & 6.26 & NS & 8.44 & 8.33 & NS & 8.31 & 7.63 & NS & 2.16 & 2.16 & NS & 8.06 & NS \\
\hline $\mathrm{CV} \%$ & 8.98 & 9.10 & 10.98 & 8.70 & 8.55 & 13.40 & 10.65 & 9.40 & 9.84 & 9.36 & 8.84 & 12.45 & 7.19 & 7.25 \\
\hline
\end{tabular}


Table.2 Effect of soaking treatments on growth parameters of elephant foot yam cv. Gajendra

\begin{tabular}{|c|c|c|c|c|c|c|c|c|c|}
\hline \multirow[t]{3}{*}{ Treatments } & \multicolumn{9}{|c|}{ Growth parameters } \\
\hline & \multicolumn{3}{|c|}{ Canopy spread N-S } & \multicolumn{3}{|c|}{ Number of leaflets } & \multicolumn{3}{|c|}{ Days required for senescence } \\
\hline & 90 DAP & 120 DAP & 150 DAP & 90 DAP & 120 DAP & 150 DAP & $1^{\text {st }}$ & $50 \%$ & Complete \\
\hline $\mathbf{T}_{1}$ & 68.33 & 71.40 & 73.00 & 297.53 & 301.00 & 311.93 & 190.33 & 199.67 & 205.00 \\
\hline $\mathbf{T}_{2}$ & 63.60 & 70.93 & 72.87 & 294.67 & 310.80 & 303.93 & 191.00 & 200.67 & 204.33 \\
\hline $\mathbf{T}_{3}$ & 64.93 & 70.00 & 72.00 & 293.47 & 285.53 & 288.93 & 187.67 & 197.33 & 204.00 \\
\hline $\mathbf{T}_{4}$ & 62.13 & 66.47 & 69.67 & 241.00 & 279.33 & 283.87 & 188.67 & 198.33 & 201.00 \\
\hline $\mathbf{T}_{5}$ & 62.20 & 68.67 & 70.33 & 286.13 & 283.93 & 286.33 & 185.67 & 195.00 & 202.67 \\
\hline$T_{6}$ & 60.87 & 68.47 & 68.67 & 252.40 & 275.07 & 283.87 & 186.33 & 196.00 & 201.33 \\
\hline $\mathbf{T}_{7}$ & 54.80 & 64.47 & 67.13 & 233.00 & 246.33 & 253.27 & 188.00 & 197.33 & 202.00 \\
\hline $\mathrm{T}_{8}$ & 54.46 & 61.33 & 65.33 & 204.47 & 242.27 & 244.53 & 188.67 & 198.33 & 202.67 \\
\hline $\mathbf{T}_{9}$ & 56.93 & 64.80 & 67.67 & 233.60 & 258.40 & 262.47 & 188.33 & 198.00 & 203.00 \\
\hline $\mathbf{T}_{10}$ & 54.80 & 62.87 & 65.33 & 211.13 & 242.33 & 250.60 & 189.00 & 198.67 & 203.33 \\
\hline $\mathrm{T}_{11}$ & 53.53 & 65.60 & 68.33 & 199.47 & 274.67 & 271.87 & 185.00 & 194.67 & 200.67 \\
\hline SEm \pm & 3.84 & 2.72 & 2.94 & 15.07 & 14.94 & 13.49 & 0.32 & 0.35 & 0.40 \\
\hline C. D. $(5 \%)$ & NS & NS & NS & 44.47 & 44.08 & 39.80 & 0.94 & 1.04 & 1.19 \\
\hline $\mathrm{CV} \%$ & 11.14 & 7.06 & 7.38 & 10.46 & 9.49 & 8.45 & 0.29 & 0.31 & 0.35 \\
\hline
\end{tabular}


Table.3 Effect of soaking treatments on yield and quality parameters of elephant foot yam cv. Gajendra

\begin{tabular}{|c|c|c|c|c|c|c|c|c|c|}
\hline \multirow[b]{2}{*}{ Treatments } & \multicolumn{5}{|c|}{ Yield parameters } & \multicolumn{4}{|c|}{ Quality parameters } \\
\hline & $\begin{array}{l}\text { Corm } \\
\text { diameter } \\
(\mathrm{cm})\end{array}$ & $\begin{array}{l}\text { Number } \\
\text { of cormels } \\
\text { per corm }\end{array}$ & $\begin{array}{c}\text { Corm } \\
\text { yield } \\
\text { per } \\
\text { plant } \\
\text { (kg) }\end{array}$ & $\begin{array}{l}\text { Corm } \\
\text { yield per } \\
\text { plot }(\mathbf{k g})\end{array}$ & $\begin{array}{c}\text { Corm } \\
\text { yield per } \\
\text { hectare } \\
\text { (tonne) }\end{array}$ & $\begin{array}{l}\text { Dry matter } \\
\text { content } \\
(\%) \text { of } \\
\text { corm }\end{array}$ & $\begin{array}{c}\text { Starch } \\
\text { content } \\
(\%)\end{array}$ & $\begin{array}{c}\text { Calcium } \\
\text { oxalate } \\
\text { content } \\
(\%)\end{array}$ & $\begin{array}{l}\text { Vitamin-A } \\
\text { content } \\
\text { (IU) }\end{array}$ \\
\hline $\mathbf{T}_{1}$ & 14.83 & 3.00 & 1.315 & 17.367 & 30.15 & 32.43 & 17.80 & 0.0209 & 146.33 \\
\hline $\mathbf{T}_{2}$ & 14.73 & 1.47 & 1.237 & 16.367 & 28.41 & 32.60 & 17.57 & 0.0218 & 147.13 \\
\hline $\mathbf{T}_{3}$ & 13.80 & 3.13 & 1.208 & 16.167 & 28.07 & 31.40 & 16.97 & 0.0213 & 143.43 \\
\hline $\mathbf{T}_{4}$ & 13.50 & 1.93 & 1.130 & 15.700 & 27.26 & 31.33 & 16.97 & 0.0207 & 142.73 \\
\hline $\mathbf{T}_{5}$ & 13.69 & 2.00 & 1.151 & 16.167 & 28.07 & 29.73 & 16.43 & 0.0216 & 142.53 \\
\hline $\mathrm{T}_{6}$ & 13.17 & 1.73 & 0.940 & 15.600 & 27.08 & 29.93 & 15.83 & 0.0218 & 141.30 \\
\hline $\mathbf{T}_{7}$ & 12.17 & 1.93 & 0.898 & 14.600 & 25.35 & 26.93 & 15.83 & 0.0205 & 139.37 \\
\hline $\mathbf{T}_{8}$ & 11.50 & 1.87 & 0.830 & 14.067 & 24.42 & 27.80 & 15.80 & 0.0218 & 138.90 \\
\hline $\mathbf{T}_{9}$ & 12.43 & 1.20 & 0.906 & 15.000 & 26.04 & 28.50 & 15.83 & 0.0220 & 139.87 \\
\hline $\mathbf{T}_{10}$ & 11.97 & 1.33 & 0.888 & 14.567 & 25.29 & 28.20 & 15.57 & 0.0200 & 139.47 \\
\hline $\mathbf{T}_{11}$ & 11.30 & 0.67 & 0.818 & 13.667 & 23.73 & 27.26 & 13.97 & 0.0205 & 136.67 \\
\hline $\mathrm{SEm} \pm$ & 0.80 & 0.33 & 0.07 & 0.72 & 1.24 & 0.46 & 0.15 & 0.0004 & 0.80 \\
\hline C. D. $(5 \%)$ & 2.35 & 0.97 & 0.21 & 2.11 & 3.67 & 1.36 & 0.45 & 0.0012 & 2.37 \\
\hline CV \% & 10.63 & 30.92 & 12.14 & 8.06 & 8.06 & 2.69 & 1.65 & 3.36 & 0.98 \\
\hline
\end{tabular}


Though the difference was non-significant at other growth stages, the overall impact of thiourea $200 \mathrm{ppm}$ was positive to achieve maximum canopy spread in both directions. These results corroborate the findings of Mondal et al., (2005) who recorded more canopy spread with various soaking treatments of thiourea, $\mathrm{KNO}_{3}$ and cow dung slurry in elephant foot yam. Canopy spread was presumably due to early sprouting and better root ramification as reported by Sen and Das (1991).

The data depicted in table 2 revealed that different soaking treatment had significant effect on number of leaflets per plant at all three growth stages. At the age of 90 days the maximum number of leaflets (297.53) per plant was recorded with $\mathrm{T}_{1}$ treatment but statistically remained at par with $\mathrm{T}_{2}, \mathrm{~T}_{3}$ and $\mathrm{T}_{5}$ treatments. After 120 DAP the maximum number of leaflets (310.80) per plant was obtained from $\mathrm{T}_{2}$ treatment which was remained at par with $\mathrm{T}_{1}, \mathrm{~T}_{3}, \mathrm{~T}_{5}, \mathrm{~T}_{4}$ and $\mathrm{T}_{6}$ treatments. At 150 DAP the maximum number of leaflets (311.93) was recorded again in $T_{1}$ treatment. This was statistically remained at par with $\mathrm{T}_{2}, \mathrm{~T}_{3}, \mathrm{~T}_{5}, \mathrm{~T}_{4}$ and $\mathrm{T}_{6}$ treatments. Shanu et al., (2013) observed that thiourea maintained more number of green leaves and this was supported by the results of Sahu et al., (1993) also.

The data given in table 2 showed that the maximum number of days (191.00 days) required for first senescence was recorded in treatment $\mathrm{T}_{2}$ (Thiourea - $300 \mathrm{ppm}$ ) which was statistically remained at par with treatment $\mathrm{T}_{1}$ (Thiourea - $200 \mathrm{ppm}$ ) which took only 0.67 less days for first senescence. The maximum number of days (200.67 days) required for 50 $\%$ senescence was also recorded in treatment $\mathrm{T}_{2}$ (Thiourea - $300 \mathrm{ppm}$ ) and was statistically remained at par with treatment $\mathrm{T}_{1}$ (Thiourea 200 ppm) which took 199.67 days for $50 \%$ senescence. Whereas, the longest period required for complete senescence (205.00 days) was recorded with $\mathrm{T}_{1}$ (Thiourea - 200 ppm) treatment but it was statistically remained at par with $T_{2}$ and $T_{3}$ treatments which required 204.33 days and 204.00 days, respectively for complete senescence. It might be due to the function of thiourea that concomitantly increase cell metabolic rate and retard senescence by protecting and preventing chloroplasts from senescing and retarding chlorophyll destruction and/or increase chlorophyll biosynthesis. This was supported by the findings of Jocelyn, 1972 who studied chemical properties of thiols.

The significant effect of all growth parameters also provided support for a possibility that thiourea might have resulted into creation of more photosynthetically active leaf for longer period, leading to more absorption and utilization of radiant energy which ultimately resulted in higher plant height, number of leaflets, canopy spread and culm girth. Similar, results were reported by Solanki (2002) in cluster bean and Balai (2005) in coriander.

Soaking treatment of corm setts gave significant differences on yield and yield attributing characters like corm diameter, number of cormels per corm, corm yield per plant, corm yield per plot and yield per hectare (Table 3). Significant influence was observed on corm diameter by different soaking treatments. The highest corm diameter $(14.83 \mathrm{~cm})$ was recorded in treatment $\mathrm{T}_{1}$ (Thiourea - $200 \mathrm{ppm}$ ) which was statistically remained at par with $\mathrm{T}_{2}, \mathrm{~T}_{3}, \mathrm{~T}_{5}, \mathrm{~T}_{4}$ and $\mathrm{T}_{6}$ treatments having $14.73 \mathrm{~cm}, 13.80 \mathrm{~cm}$, $13.69 \mathrm{~cm}, 13.50 \mathrm{~cm}$ and $13.17 \mathrm{~cm}$ corm diameter, respectively. This might be due to early sprouting of corm setts in these treatments which resulted into sufficient vegetative growth and canopy spread which in turn to higher photosynthesis, increased assimilates and translocation of these 
assimilates to the resulting corms thereby increasing their diameter (Kumar et al., 2009). Ample energy may be made available for the bulking of corms due to improvement in vegetative characters of plants. Similar results were reported by Mohankumar et al., (1973) in elephant foot yam.

Treatment $\mathrm{T}_{1}$ (Thiourea $200 \mathrm{ppm}$ ) resulted in maximum corm yield per plant $(1.315 \mathrm{~kg})$ which was statistically at par with $\mathrm{T}_{2}, \mathrm{~T}_{3}, \mathrm{~T}_{5}$ and $\mathrm{T}_{4}$ which produced corm weight of $1.237 \mathrm{~kg}$, $1.208 \mathrm{~kg}, 1.151 \mathrm{~kg}$ and $1.130 \mathrm{~kg}$ per plant, respectively. Among different treatments, $\mathrm{T}_{1}$ (Thiourea - $200 \mathrm{ppm}$ ) treatment produced highest corm yield $(17.367 \mathrm{~kg})$ per net plot which was statistically remained at par with $\mathrm{T}_{2}$ (16.367 kg/net plot), $\mathrm{T}_{3}\left(16.167 \mathrm{~kg} / \mathrm{net}\right.$ plot), $\mathrm{T}_{5}$ (16.167 kg/net plot), $\mathrm{T}_{4}(15.700 \mathrm{~kg} /$ net plot) and $\mathrm{T}_{6}(15.600 \mathrm{~kg} / \mathrm{net}$ plot $)$ treatments. This corm yield was when converted on hectare basis, the highest corm yield of $30.15 \mathrm{t} \mathrm{ha}^{-1}$ was produced in treatment $T_{1}$ which was statistically remained at par with $\mathrm{T}_{2}, \mathrm{~T}_{3}, \mathrm{~T}_{5}, \mathrm{~T}_{4}$ and $\mathrm{T}_{6}$ treatments, which produced $28.41 \mathrm{t} \mathrm{ha}^{-1}, 28.07 \mathrm{t} \mathrm{ha}^{-1}, 28.07$ $\mathrm{t} \mathrm{ha}^{-1}, 27.26 \mathrm{t} \mathrm{ha}^{-1}$ and $27.08 \mathrm{t} \mathrm{ha}^{-1}$, respectively. Increase in corm yield under this treatment might be ascribed to comparatively greater individual growth and development of plants due to early sprouting and vigour. The increase in yield attributes and yield obtained with thiourea treatment was most probably due to increased photosynthesis favoured by both improved photosynthesis effect and source to sink relationship (Anonymous, 2002). These results are in conformity with the findings of (Nedunchezhiyan and Mohankumar, 1994; Kumar et al., 1998; Bhagavan, 2005). Dhua et al., 1988 and Das et al., 1995 also reported outstanding performance of these substances in increasing the corm yield. Shant and Singh, 1985 reported that when thiourea was applied as seed soaking, exhibited growth regulating effect. Vassilev and Mashev, 1974 also observed that thiourea exhibited the activities like cytokinin.

Analysis of dry matter content, starch content, calcium oxalate content and $\beta$-carotene content from the corm of elephant foot yam was carried out as per the standard methods. The highest dry matter content $(32.60 \%)$ of corm was analysed in treatment $T_{2}$ (Thiourea $300 \mathrm{ppm}$ ) which was statistically remained at par with treatments $\mathrm{T}_{1}, \mathrm{~T}_{3}$ and $\mathrm{T}_{4}$ which had $32.43 \%$, $31.40 \%$ and $31.33 \%$ dry matter content. Sahu and Singh (1995) observed that thiourea affects both carbohydrates and nitrogen metabolism which in turn enhances plant performance and increased dry matter production and yield. The minimum number of cormels per corm (0.67) was recorded on the corms produced in control $\left(\mathrm{T}_{11}\right)$ which was statistically remained at par with treatments $\mathrm{T}_{9}(1.20), \mathrm{T}_{3}(1.33)$ and $\mathrm{T}_{4}$ (1.47). The maximum starch content of $17.80 \%$ was found in $\mathrm{T}_{1}$ (Thiourea $200 \mathrm{ppm}$ ) treatment and was at par with $\mathrm{T}_{2}(17.57 \%)$ treatment. Thiourea also plays an important role in maximizing starch accumulation in the corms. Shanu et al., (2013) observed that thiourea with its sulphydral group not only favoured larger green photosynthetic surface but it might have also favoured the activity of starch synthetase in coriander. It might be due to the fact that thiourea molecule is a good donor of sulphur atoms in biological reactions (Randle and Bussard, 1993). Balai and Keshwa (2011), observed that application of thiourea increases the total uptake of $\mathrm{N}, \mathrm{P}$ and $\mathrm{K}$ and creates lighter microbial population in soil which is responsible for mobilizing essential nutrients which may increase starch content. The lowest calcium oxalate content $(0.0200 \%)$ was found in treatment $\mathrm{T}_{10}(\mathrm{MH} 500 \mathrm{ppm})$ which was statistically remained at par with $\mathrm{T}_{11}(0.0205$ $\%), \mathrm{T}_{7}(0.0205 \%), \mathrm{T}_{4}(0.0207 \%)$ and $\mathrm{T}_{1}$ $(0.0209 \%)$ treatments. Higher $\beta$-carotene content (147.13 IU) was found in treatment $\mathrm{T}_{2}$ (Thiourea- $300 \mathrm{ppm}$ ) which was statistically remained at par with $\mathrm{T}_{1}$ (146.33 IU) treatment. It might be due to the fact that production of these quality parameters was possible only at the later stages of development of plant and tuber growth when compared to early stages of their harvest. In the present study early emergence and delayed maturity were noted under these treatments which may have enhanced opportunity for accumulation of beta 
carotene over longer period. Similar results have been reported by Bhagavan (2005) and Ashokan et al., (1984).

On the basis of present findings inferred that effect of chemicals had highly influenced on vegetative, yield and quality parameters. The pre-planting soaking of setts in thiourea @ 200 ppm was found better for boosting up the production of elephant foot yam cv. Gajendra.

\section{References}

A.O.A.C., (1960). Official methods of analysis, 18th ed. Association of official agriculture chemats 16 , Washington DC. 20044.

Anonymous (2002). Research Highlights. Directorate of Research, Rajasthan Agricultural University, Bikaner.

Ashokan, P. K., Gopinathan, V. K. and Vikraman, Nair. R. (1984). Response of Amorphophallus to size of seed corm and manures. J. Root Crops, 10 (1\&2): 51-54.

Balai, L. R. (2005). Effect of thiourea on growth and productivity of coriander (Coriandrum sativum L.) varieties under normal and late sown conditions. Ph. D. Thesis, Rajasthan Agricultural University, Bikaner.

Balai, L. R. and Keshwa, G. L. (2011). Effect of thiourea on yield and nutrient uptake of coriander (Coriandrum sativum L.) varieties under normal and late sown conditions. J. Spice and Aromatic Crops, 20 (1): 34-37.

Bhagavan, B. V. K. (2005). Standardization of production technology, storage methods and dormancy breaking techniques for production of quality planting material of elephant foot yam Amorphophallus paeoniifolius (Dennst). Ph. D. Thesis, submitted to Acharya N. G. Ranga Agricultural University, Hyderabad, Andhrapradesh, India.

Burguillo, P. and Gregorio, N. (1997). Appearance of an alternate pathway cyanide resistant during germination of seeds of Cicer arietinum. Plant Physio. 60: 524-527.

Das, P. K., Sen, H., Banerjee, N. C. and Panda, P. K. (1995). Sprouting, growth and whole seed corm production of elephant foot yam as affected by soaking of bottom corm setts in chemicals. Indian Agriculturist, 39 (3): 179-185.

Dhua, R. S., Ghosh, S. K., Biswas, J., Mitra, S. K. and Sen, H. (1988). Effect of some chemicals on sprouting, growth and corm yield of Amorphophallus campanulatus. J. Root crops, 14 (2): 47-49.

Jocelyn, P. C. (1972). Biochemistry of $-\mathrm{SH}$ group: The Occurrence, Chemical Properties, Metabolism and Biological Function of Thiols and Di-sulphides. Academic Press, London.

Kumar, D. A., Indira, P. and Nambisan, B. (1998). Effect of light and growth regulators on sprouting of Amorphophallus tubers. Tropical Sci., 38 (4): 187-189.

Kumar, K., Suresh., Chandrashekar, R., Padma, M. and Shivashankar, A. (2009). Effect of plant growth regulators on dormancy, corm and cormel production in gladiolus (Gladiolus $\times$ grandiflorus L.). J. Orn. Hort., 12 (3): 182-187.

Mohankumar, C. R., Mandal, R. C. and Singh, K. D. (1973). Effect of mulching and plant density on growth, yield and quality of Amorphophallus. Indian J. Agron., 18: $62-66$.

Mondal, S., Sen, H., Tarafdar, J. and Chattopadhyay, A. (2005). Whole seed corm production of elephant foot yam through mini bottom corm setts soaked with growth substances and cow dung slurry. The Hort. J., 18 (2): 102-105.

Naveen, P. Kumar., Reddy, Y. N. and Chandra Shekar, R. (2011). Effect of different chemicals on breaking dormancy, growth and flowering of gladiolus cultivars. Indian J. Hort., 68 (4): 540-546.

Nedunchezhiyan, M. and Mohankumar, C. R. (1994). Effect of pre-treatments in breaking dormancy and inducing sprouts 
in elephant foot yam. J. Root crops, 20 (2): 138-140.

Nedunchezhiyan, M., Jata, S. K., Mukherjee, A. and Misra, R. S. (2011). Impact of growth regulators on cormel production and dormancy breaking in elephant foot yam [(Amorphophallus paeoniifolius) (Dennst.) Nicolson]. J. Root Crops, 37 (1): 24-28.

Nedunchezhiyan, M., Misra, R. S. and Shivalingaswamy, T. M. (2002). Elephant foot yam (Amorphophallus paeoniifolius (Dennst.) Nicolson) as an intercrop in banana and papaya. Orissa J. Hort., 30 (1): $80-82$.

Nicolson, D. H. (1987). Araccae. In: A Revised hand book to the flora of Ceylon, Dassanayake, M. D. and Foseberg, F. R. (Eds). Vol. vi Amerind publishing Co. Pvt. Ltd., New Delhi, India. Pp: 17- 101.

Padmaja, G., Moorthy, S. N., Bala, N., Lila Babu; Sundaresan, S., Sajeev, M. S., Nanda, S. K., Jhon, K. S., Rajalekshmy, L., Devi, K. S. S. and Nair, M. (2005). "Analytical methodologies for tropical tuber crops", CTCRI, Trivandrum. Pg. no. 9-12 \& 26-27.

Randle, W. M. and Bussard, M. L. (1993). Pungency and sugars of short day onions as affected by $\mathrm{S}$ nutrition. J. American Soc. Hort. Sci., 118 (6): 766-770.

Ravi, V., Ravindran, C. S. and Suja, G. (2009). Growth and productivity of elephant foot yam [Amorphophallus paeoniifolius (Dennst.) Nicolson]: an overview. J. Root Crops, 35(2): 131-142.

Sahu, M. P. and Singh, D. (1995). Role of thiourea in improving productivity of wheat (Triticum aestivum L.). J. Plant Growth Regulation 14: 169-173.

Sahu, M. P., Solanki, N. S. and Dashora, N. L. (1993). Effect of thiourea, thiamine and ascorbic acid on growth and yield of maize (Zea mays L.). J. Agron. \& Crop Sci. 171: 65-69.

Sen, H. and Das, P. K. (1991). Effect of cut and whole seed corm of same size on growth and yield of elephant foot yam. J. Root Crops, 17: 151-153.

Shant, P. S. and Singh, M. (1985). Effect of gibberallic acid and thiourea on seedling growth of wild olive (Oleo cuspidate) Res. Develop. Ref. Jammu 12: 36-41.

Shanu, I. S., Naruka, P. P., Singh, R. P. S., Shaktawat and Verma, K. S. (2013). Effect of seed treatment and foliar spray of thiourea on growth, yield and quality of coriander (Coriandrum sativum L.) under different irrigation levels. Int. J. Seed Spices 3 (1): 20-25.

Solanki, N. S. (2002). Effect of thiourea and demethyl sulphoxideon phosphorus use efficiency, dry matter partitioning and productivity of clusterbean [Cyamopsis tetragonoloba (L.) Taub.]. Ph. D. Thesis, Maharana Pratap University of Agriculture and Technology, Udaipur.

Vassilev, G. N. and Mashev, N. P. (1974). Synthesis, chemical structure and cytokinin like activity of some derivatives of $\mathrm{N}$-phenyl $-\mathrm{N}$ like or aryl thiourea and their influences on nitrogen metobolism in barley seedlings. Biochemie Physiology Pflanzen 165: 467-478.

\section{How to cite this article:}

Samatha Punna, K.D. Desai, B.M. Tandel and Harish Suthar. 2018. Effect of Chemicals on Growth, Yield and Quality of Elephant Foot Yam [Amorphophallus paeoniifolius (Dennst.) Nicolson]. Int.J.Curr.Microbiol.App.Sci. 7(08): 1295-1304. doi: https://doi.org/10.20546/ijcmas.2018.708.146 